\title{
Invited commentary
}

\section{The effects of iron and copper status and of dietary carbohydrates on the activity of rat intestinal $\beta$-carotene $15,15^{\prime}$-dioxygenase}

In much of the world, the primary dietary sources of vitamin A (an essential nutrient for vision, the immune system, reproduction and growth) are coloured fruits and vegetables rich in carotenoids (Underwood \& Arthur, 1996; Olson, 1999). A sobering fact in this regard is that millions of young children, pregnant women and lactating mothers do not ingest enough carotenoids and vitamin A to fulfil their physiological needs (Sommer \& West, 1996; Underwood \& Arthur, 1996; Olson, 1999). As a consequence, a variety of public health strategies are being used to improve the vitamin A statuses of these at risk groups (Sommer \& West, 1996; Underwood \& Arthur, 1996).

Two factors primarily determine the amount of vitamin A that is derived from dietary carotenoids: (1) the bioavailability of the ingested food carotenoids (Castenmiller \& West, 1998; Olson et al. 1999) and (2) the mechanism of conversion of provitamin A carotenoids into vitamin A. In the former instance, the widely accepted view that, on average, $6 \mu \mathrm{g}$ all-trans $\beta$-carotene in food is equivalent to $1 \mu \mathrm{g}$ all-trans retinol is being re-evaluated; (2) the question of whether a molecule of $\beta$-carotene is cleaved to one or to two molecules of vitamin A has been debated since 1960 (Olson, 1999). Central cleavage of $\beta$-carotene to two molecules of vitamin A clearly seemed to be the major pathway in the mid-1960s (Goodman \& Huang, 1965; Olson \& Hayaishi, 1965), but interest in the stepwise cleavage of $\beta$-carotene to one molecule of vitamin A has recently resurged (Wang \& Krinsky, 1998). The current view is that central cleavage is clearly the predominant pathway in healthy animals and human subjects (Nagao et al. 1996), although stepwise cleavage is enhanced in intestinal tissue by oxidative stress (Wang \& Krinsky, 1998; Olson, 1999).

The central cleavage of $\beta$-carotene into retinal, the immediate product, requires molecular $\mathrm{O}$. The postulated mechanism is that a molecule of $\mathrm{O}$ adds across the central $\left(15,15^{\prime}\right)$ double bond of $\beta$-carotene to give an unstable dioxetane ring, which then rearranges with cleavage to yield two molecules of retinal (Olson, 1999). Most dioxygenases require metal ions, usually $\mathrm{Fe}$ or $\mathrm{Cu}$, to bind $\mathrm{O}$ initially at the active site of the enzyme. In support of this view, O-phenanthroline and $\alpha, \alpha^{\prime}$-dipyridyl, which bind strongly to $\mathrm{Fe}$, inhibit the enzyme (Olson \& Hayaishi, 1965; Olson, 1999). In contrast, the storage of vitamin A formed from $\beta$-carotene seems to be normal in Fe-deficient rats (Swanson \& Parker, 1993) and normal or enhanced in Cu-deficient rats (Rachman et al. 1987; Dulin et al. 1995). Finally, because the cleavage enzyme has never been highly purified, uncertainty has continued to exist about the possible role of metals in its activity.
Fe and $\mathrm{Cu}$ are closely linked both physiologically and nutritionally (Fairbanks, 1999; Turnlund, 1999). In the transport of $\mathrm{Fe}$ from the intestinal mucosa into the plasma, the oxidation of Fe from the ferrous to the ferric state, which then is bound to transferrin, is catalysed by caeruloplasmin (ferroxidase I) and ferroxidase II, both $\mathrm{Cu}$-containing proteins. Furthermore, $\mathrm{Cu}$ and $\mathrm{Fe}$ are necessary components of cytochrome oxidase, the terminal enzyme of electron transport in the reduction of $\mathrm{O}$ to $\mathrm{H}_{2} \mathrm{O}$. Finally, $\mathrm{Cu}$ also seems to be involved in the formation of erythrocytes. Thus, at least at three key points in the utilization and function of $\mathrm{Fe}, \mathrm{Cu}$ is required. The intestinal absorption of Fe, however, does not seem to require $\mathrm{Cu}$ (Fairbanks, 1999).

Thus, in $\mathrm{Cu}$ deficiency, anaemia would be expected, probably associated with a decline in energy production and an accumulation of $\mathrm{Fe}$ in internal organs. In rats, but not necessarily in other species, fructose or sucrose, when substituted for maize starch in the diet, seems to enhance the onset of $\mathrm{Cu}$ deficiency (Turnlund, 1999).

That preamble brings us to the interesting paper by During et al. (2000) published in this issue of the British Journal of Nutrition. Groups of rats were fed low, medium or high amounts of ferric citrate in combination with a $\mathrm{Cu}$ deficient or $\mathrm{Cu}$-adequate diet. Either starch or fructose was supplied as the carbohydrate source. The question was: 'What effect do these different dietary regimens have on the carotene cleavage enzyme in the intestine?' Let us consider first the starch-fed rats.

In $\mathrm{Cu}$-deficient rats, the concentration of $\mathrm{Fe}$ in the liver, but rather oddly, not in the intestinal mucosa, expectedly doubled at the higher two levels of Fe intake. The activity of the intestinal cleavage enzyme was also consistently higher in $\mathrm{Cu}$-deficient than in $\mathrm{Cu}$-sufficient rats and was directly proportional to the Fe content of the intestinal mucosa.

When fructose was fed, the effects of $\mathrm{Cu}$-deficient diets on tissue concentrations of $\mathrm{Cu}$ and $\mathrm{Fe}$ were similar to those seen with starch, except that the $\mathrm{Cu}$ concentration in the intestinal mucosa, oddly enough, was higher than with starch. On the other hand, the activity of the intestinal cleavage enzyme in fructose-fed, Cu-deficient rats was higher than in starch-fed, deficient rats. Thus, although none of the rats was highly deficient in $\mathrm{Cu}$, as indicated by significant amounts in the tissues, dietary fructose did reduce the growth rate of the rats relative to the starch-fed groups and did enhance carotene cleavage activity.

So what does this study tell us? First, the cleavage enzyme clearly does not require $\mathrm{Cu}$ for activity. Second, the enzyme activity is proportional to the Fe content of the tissue, which reflects that in the diet. This latter finding is 
a bit surprising, in that one might expect the enzyme to sequester Fe, such that its activity would reach an optimum at medium intake levels of Fe. As the level of dietary Fe also enhanced cleavage activity in $\mathrm{Cu}$-sufficient rats fed on fructose, but not in those fed on starch, however, other factors are clearly at work here. This study confirms and extends recent studies of the same group (During et al. 1999) that $\mathrm{Fe}$ is essential for carotenoid cleavage.

The number of factors, therefore, that influence the activity of the intestinal carotenoid cleavage enzyme keeps growing. The intestinal enzyme activity is enhanced by vitamin A deficiency, polyunsaturated fats in the diet, $\mathrm{Cu}$ depletion, fructose feeding, and glutathione, and is inhibited by protein deficiency, heavy metals that bind to its essential sulfhydryl groups, and some aromatic phytochemicals. Whether carotenoid cleavage enzymes in the liver and other organs are similarly affected merits attention.

In closing, it makes sense that an enzyme responsible for vision and for the integrity of several key physiological processes for the vast majority of humans worldwide would be influenced both by nutritional status and by diet. Further developments must certainly be in the offing.

\section{James Allen Olson Department of Biochemistry, Biophysics \& Molecular Biology Iowa State University Ames, IA 50011 \\ USA}

\section{References}

Castenmiller JJM \& West CE (1998) Bioavailability and bioconversion of carotenoids. Annual Review of Nutrition 18, 19-38.

Dulin A, Bieri JG \& Smith JC (1995) Copper deficiency does not affect conversion of $\beta$-carotene to vitamin $\mathrm{A}$ in rats. Nutrition Research 15, 589-594.

During A, Fields M, Lewis CH \& Smith JC (1999) $\beta$-Carotene $15,15^{\prime}$-dioxygenase activity is responsive to copper and iron concentrations in rat small intestine. Journal of the American College of Nutrition 18, 309-315.

During A, Fields M, Lewis CG \& Smith JC (2000) Intestinal $\beta$-carotene $15,15^{\prime}$-dioxygenase activity is markedly enhanced in copper-deficient rats fed on high-iron diets and fructose. British Journal of Nutrition 84, 117-124.

Fairbanks VF (1999) Iron in medicine and nutrition. In Modern Nutrition in Health and Disease, 9th ed., pp. 193-221 [ME Shils, JA Olson, M Shike and AC Ross, editors]. Baltimore, MD: Williams and Wilkins.

Goodman DS \& Huang HS (1965) Biosynthesis of vitamin A with rat intestinal enzymes. Science 149, 879-880.

Nagao A, During A, Hoshino C, Terao \& Olson JA (1996) Stoichiometric conversion of all-trans- $\beta$-carotene to retinal by pig intestinal extract. Archives of Biochemistry and Biophysics 328, 57-63.

Olson JA (1999) Carotenoids. In Modern Nutrition in Health and Disease, 9th ed., pp. 525-542 [ME Shils, JA Olson, M Shike and AC Ross, editors]. Baltimore, MD: Williams and Wilkins.

Olson JA \& Hayaishi O (1965) The enzymatic cleavage of betacarotene into vitamin A by soluble enzymes of rat liver and intestine. Proceedings of the National Academy of Sciences USA 54, 1364-1370.

Olson JA, Parker RS, Reddy V, Rodriguez-Amaya DB, Smitasiri S \& Tsou SCS (1999) The bioavailability of dietary carotenoids: current concepts. International Vitamin A Consultation Group. Washington, DC: ILSI Press.

Rachman F, Conjat F, Carreau JP, Bleiberg-Daniel F \& AmedeeManeseme O (1987) Modification of vitamin A metabolism in rats fed a copper-deficient diet. International Journal for Vitamin and Nutrition Research 57, 247-252.

Sommer A \& West KP Jr (1996) Vitamin A deficiency: Health, survival, and Vision, pp. 438. Oxford: Oxford University Press.

Swanson JE \& Parker RS (1993) Effect of iron on liver vitamin A and $\beta$-carotene stores in rats fed $\beta$-carotene as sole source of vitamin A. FASEB Journal 7, A276 Abstr.

Turnlund JR (1999) Copper. In Modern Nutrition in Health and Disease, 9th ed., pp. 241-252 [ME Shils, JA Olson, M Shike and AC Ross, editors]. Baltimore, MD: Williams and Wilkins.

Underwood BA \& Arthur P (1996) The contribution of vitamin A to public health. FASEB Journal 9, 1040-1048.

Wang XD \& Krinsky NI (1998) The bioconversion of $\beta$-carotene into retinoids. Subcellular Biochemistry 30, 159-180. 